\title{
Social Construction of Commercial Sex Workers at Nightclub in Palangka Raya
}

\author{
Sucita Anggraeni', Dhanu Pitoyo ${ }^{2}$ \\ ${ }^{1}$ Postgraduate Program of Sociology, Faculty of Social Science and Political Science, Universitas Palangka Raya, \\ Indonesia \\ ${ }^{2}$ Department of Sociology, Faculty of Social Science and Political Science, Universitas Palangka Raya, \\ Indonesia \\ sucita312@gmail.com
}

\begin{abstract}
This study aims to analyze Commercial Sex Workers (CSWs) in night clubs in the city of Palangka Raya with a review of social construction. Data obtained based on the results of in depth interviews during the months of June to August 2018 with three CSWs who are willing to be interviewed are supported from relevant secondary data. The data is processed based on qualitative research principles based on the type of case study research. In the results of this study it was found that the CSWs could be independent or take shelter under the agency in the night club. This CSWs network generally starts from working as a Sales Promotion Girl (SPG) or song guide to the sexy dancer at the night club.
\end{abstract}

Keywords

CSWE, social construction; CSNE Network

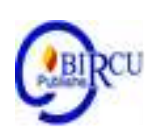

\section{Introduction}

The increasing amount of night entertainment in the city of Palangka Raya turns out to make Commercial Sex Workers (CSWs) use it to offer themselves, they can move from one night entertainment venue to another to get customers. According to Kadir (2007) in Destrianti and Harnani (2018) that the rise of sex workers in Indonesia is not a phenomenon that appears by itself. Broadly speaking, there are six reasons for the background of this work, among others because of poverty and fulfillment of life needs, dissatisfaction with work being done and income that is still considered insufficient, because they do not have enough intelligence to enter the formal sector or to pursue education levels higher, background damage or lack of family life, such as children who are not cared for and lack of parental love, heartache left by a cheating husband or remarried, because they are not satisfied with the sexual life they had before, have a physical disability.

CSWs, or in another sense also called prostitution, has been progressing pattern. For example in a special area (localization) whether it is covert or open, with online (call), or carried out incidentally. Various patterns of prostitution can be done independently or the presence of a pimp, in other terms also called mami.

Then according to Syam (2010) that commercial sex workers dare to sacrifice themselves, the future, and their lives are nothing but to get money. Though the money from hard work does not belong to him as a whole, but the money must be distributed to all parties involved in his work, such as money for pimps, money for guards, money for room rent, service fees and so on. Therefore, it is very fair to say that they are also the most disadvantaged group of sexual-contractual exchanges between sex workers and their clients. 
One of the places that can be used as a place for prostitution is a night club, because nightclubs don't only provide entertainment for example karaoke bars but can also provide sexual service facilities to customers. From the facilities provided by the sexual service providers, it was found interesting to the researchers, that the female entertainment workers tonight have their own work systems that can be used to get "links" from various groups. So it is not uncommon to see various people with work backgrounds in the nightclubs.

In this case it is based on night women who are usually formed by the agency's work system both karaoke and night club. These agencies form a group that combines several women night workers because of specific purposes such as connecting one woman to another to find customers. The term "link" that the researchers mean is, in the form of a network that connects customers with female night entertainment workers.

Based on the results of preliminary observations conducted by researchers on one night entertainment in the City of Palangka Raya, it is known that there are activities of several female night entertainment workers who are connected with the same consumer. Through their activities many researchers find interesting activities, namely starting from the way they operate, the network used to get customers, including tactics to survive in the field of work as they do. Their mode of operation is somewhat unique because researchers see a difference between workers who provide sexual services at nightclubs.

It is often equated the term ladies for women who work at nightclubs that provide sexual services. However, the fact that the researchers encountered during the initial observation was that some women who worked at night entertainment did not want to be confused with ladies. In the initial observation the researchers saw that there were two types of women who provided sexual services, namely the so-called ladies and women who were contacted by telephone. For the term ladies are used for women who operate through a pimp network or commonly called "mami". Through "mami" the ladies will get a job in accordance with the provisions provided by "mami". With the existence of "mami" in the work cycle of the ladies, the results that can not necessarily be the personal rights of the ladies. There is a revenue sharing system that is carried out by the ladies towards "mami" while sexual service providers by phone do not share the results with "mami" but usually they will give tips money to employees who are at nightclubs or people who contact them by telephone. Although there are tips for giving contacts, however, the amount is not so large that the benefits gained are more than the night entertainment workers commonly called ladies.

\section{Review of Literatures}

\subsection{Overview of Social Construction}

The term construction of social reality (social construction of reality) became famous since it was introduced by Peter L. Berger and Thomas Luckmann through his book entitled The Social Construction of Reality: A Treatise in the Sociological of Knowledge (1966). He described the social process through his actions and interactions, in which individuals create continuously a reality that is shared and subjectively experienced together.

According to Suparno (1997) there are three types of constructivism: first, radical constructivism; second, hypothetical realism: third, ordinary constructivism. Radical constructivism can only acknowledge what is formed by our minds. This form is not always a real-world representation. Radical constructivism overrides the relationship between knowledge and reality as a criterion of truth.

Then knowledge for them does not reflect an objective ontological reality, but a reality shaped by one's experience. Hypothesis realism, knowledge is a hypothesis of the structure of 
reality that approaches reality and leads to essential knowledge. Whereas ordinary constructivism takes all the consequences of constructivism and understands knowledge as a picture of that reality. Then individual knowledge is seen as a picture formed from the reality of objects within themselves.

Berger and Luckmann (1990) in Ngangi (2011) explain social reality by separating understanding 'reality' and 'knowledge'. Reality is defined as a quality that is contained in realities that are recognized as having an existence (being) that does not depend on our own will. Whereas knowledge is defined as certainty that realities are real and have specific characteristics.

In another point of view mentioned by Frans M. Parera (Berger and Luckmann, 1990) in Mudzakir (2014) explains, the main task of the sociology of knowledge is to explain the dialectics between self and the world of socioculture. This dialectic takes place in a process with three simultaneous "moments". First, externalization (adjustment) with the sociocultural world as a human product. This adjustment is owned by every human being. In the case of the writer who is careful here externalization means the condition of the song guides or karaoke guides.

This adjustment is related to how they adapt to their customers, work environment, and how they find and attract consumers. Secondly, objectivation, namely social interactions that occur in an intersubjective world that is institutionalized or undergoes an institutionalization process. Institutions in this case relate to karaoke institutions and night clubs which are the research locations of researchers. As a place of entertainment, karaoke and nightclubs are not infrequently a place for the ongoing practice of prostitution in disguise. Social processes and actions occur through various places. Based on preliminary observations made by researchers, the karaoke place is one of the most popular nightspots at the moment.

While the third is internalization, which is the process by which individuals identify themselves with social institutions or social organizations where individuals are members. This identification is carried out by song guides through various interactions and social actions towards customers who use their services. The identification process itself does not take place immediately, usually through various opportunities we will be able to see how they identify themselves as workers in the night entertainment. This identification can be seen through behavior, how to dress, talk and behave in public places and nightclubs.

This stage of externalization takes place when social products are created in society, then the individual externalizes (self-adjustment) into the socio-cultural world as part of human products. Primary socialization is a process in which individuals engage with the social world more than merely cognitive learning. Because primary socialization takes place in conditions with high emotional content. The relationship between individuals and other people is in a very close condition and is in a primary group situation, where the child identifies himself with family members who influence various emotional ways. The process of self-identification lasts quite a long time, as long as they blend in with the location where they live, then self-identification also takes a very long time.

Primary socialization ends when the concept of other people in general and everything that comes with it, has been formed and embedded in individual consciousness. At this point he is already an effective member of society and subjectively owns a 'self' and a world.

\subsection{Social network}

To understand social networks according to Damsar (2002) that social networks are relationships that are created between many individuals in a group or a group with a group. Relationships that occur are biased in formal and informal forms. Social relations are a picture or reflection of cooperation and coordination between citizens based on active and 
reciprocal social ties. Social networks are a special type of network, where the "ties" that connect one point to another point in the network are social relations.

The concept of networking between workers in the nightclubs that exist in this study shows that each part plays their role, thus demonstrating a unified achievement of shared desires in improving economic life. The background to the emergence and development of a social networking approach in anthropological studies is that when social anthropologists begin to focus attention on more complex societies, they begin to experience difficulties or experience a lack of the structural-functional approach used. This happens because the structural-functional approach used is built through studies of a simpler society, where the changes that occur there are relatively slow.

According to Agusyanto (2007) the social network approach is simply aimed at classifying the types of bonds between individuals and sorting out patterns that are formed in relation to unrestrained behavior patterns, attitudes and actions for actors who are part of the network. The formation of social networks in society because humans can not relate to all humans, but the relationship is always limited to only a few humans. So to choose and develop the most appropriate social relationships of all social relations in society, humans really need a learning process.

Then the social network has a function as a messenger, which can then be carried out in the form of actions that must be acceptable and included as a part of the knowledge system of the person receiving the message, and in its implementation it must be possible or supported by the social structure prevailing in the local community. By Suparlan (1983) in his classic work states that in reality, social networks that exist under the territory that is realized based on the basis of interpersonal relations can be a means of spreading the message and influence on decision making and implementing decisions that have been taken regarding its involvement in the message.

Social relations where each individual is attached can be seen as a network. Social networks can be seen as a small number of dots connected by lines. These points can be people, roles, positions, status, groups, neighbors, organizations, communities, countries and so on. This line can be an embodiment of social relations between individuals, meetings, kinship, exchanges, subordinate relations, relations between organizations, military alliance and so on.

\section{Research Methods}

This study uses a qualitative research method with descriptive analysis, it aims to provide a complete data analysis of the Social Construction of Commercial Sex Worker Networks Through Night Entertainment in the City of Palangka Raya. The data obtained is natural, the researcher in observing, interacting, and will also try to understand language and interpretation related to the object of research, and make researchers better understand the situation and field conditions.

To obtain valid data, researchers used data collection techniques by involving observation (Participant Observation), in-depth interviews, and documentation to 3 (three) key informants. In this connection the researcher visited 5 (five) nightspots in the city of Palangka Raya that were considered to be able to answer the research problem formulation.

To test the validity of the data obtained so that it actually fits the purpose and purpose of the study, the researcher uses triangulation techniques. According to Moleong (2007), data triangulation is a data checking technique that utilizes something other than the data for checking or comparison purposes. Whereas for data analysis researchers are guided by the interactive technique of Miles and Huberman in Sugiyono (2008) that the activities in 
qualitative data analysis are carried out interactively and continue continuously until completion, so that the data is already saturated. Activities in data analysis are data reduction, data display, and conclusion drawing / verification.

\section{Discussion}

\subsection{Recruitment Patterns at Nightclubs}

Recruitment is generally carried out by management through predetermined actors (agents), through advertisements on social media or groups of fellow ladies with advertising language looking for sexy dancers or song guides. Usually they write information briefly and clearly. The information is in the form of an invitation for women with proportional height and weight, aged from 18 to 27 years, beautiful faces, can dance and others. Some network actors also emphasized the main point of the applicants with the provisions that they already had permission from parents, families, and even couples that the applicants would work as sexy dancers. While detailed information regarding salary, work system, and facilities will be discussed after the applicant is accepted.

The actors are the managers or the person in charge of the night entertainment venues, usually the ones who hold great control. The recruitment process is also the task of the actors of night entertainment. In this digital era, the recruitment process is more effectively used by actors. Generally they do the process through social network services, although some of them still carry out the recruitment process in disguise.

In addition, the actors usually do not go directly to the recruitment process, they have a recruitment system carried out by certain parties, can take a long time, or by seeing that the visitors who come are indeed permanent visitors. This aims to minimize conflicts or risks that will later be accepted by workers and managers of night entertainment venues. The actors here give privileges to the workers. For example, by giving a special membership card with various facilities that are determined, giving a bonus every time the performance, security guarantees while being a sexy dancer, and access to get VIP guests.

\section{a. VIP Guests as Priority}

The ladies usually target VIP guests with appearances when in the evening entertainment which is deliberately set to give the curiosity of male visitors, for example by wearing a mini dress and with a pungent perfume, coupled with seductive communication styles plus various kinds accessories that impress a free party atmosphere.

VIP guests are usually considered to have more money and are spontaneous and do not play with ladies. When the transaction is done, it is usually from officials or businessmen that these commercial sex workers can go outside the city or region. During their regular work, the prostitutes keep asking actors (managers, assistants, mami) to arrange a meeting with the VIP themselves. Even for out-of-town trips, sometimes they ask to be accompanied by their agency, this serves as a form of supervision and security.

When traveling with colleagues or third parties, there is usually a sharing of results obtained with third parties. This is a form of gratitude as well as an effort to build good relations with the dealer so that later they will always get VIP guests in the future.

\section{b. Rates Specified}

The amount of tariffs set by female entertainers who can become CSWs in accordance with the agreed agreements and facilities obtained by guests who use the services of female entertainers can be seen in the table below : 
Table 1. Hostes Rates, Ladies, and Women Calls

\begin{tabular}{|c|c|c|}
\hline $\begin{array}{c}\text { Female } \\
\text { Comforter Type }\end{array}$ & $\begin{array}{l}\text { Rates in Hours and } \\
\text { Days }\end{array}$ & Facilities Provided \\
\hline $\begin{array}{l}\text { Independent song } \\
\text { guide without } \\
\text { sexual intercourse }\end{array}$ & Rp.200,000 / hour & $\begin{array}{l}\text { Pick songs, singing, dancing, and pour alcoholic } \\
\text { beverages (if any drinks). }\end{array}$ \\
\hline Song Guides ++ & $\begin{array}{l}\text { Rp. } 200,000 \text { / hour } \\
\text { * excluding sexual } \\
\text { relationship rates }\end{array}$ & $\begin{array}{l}\text { Choosing a song, singing, dancing, massaging } \\
\text { (if it is cold), pouring drinks (if there are drinks) } \\
\text { and making an agreement on whether to proceed } \\
\text { to the stage of sexual intercourse or not. }\end{array}$ \\
\hline $\begin{array}{l}\text { Ladies } \\
\text { Companion }\end{array}$ & Rp.200.000/hour & $\begin{array}{l}\text { Pick songs, dancing and singing, doing activities } \\
\text { such as teasing the guests, and provide sexual } \\
\text { services after the completion of a karaoke } \\
\text { together if guests want to have sex during work } \\
\text { hours karaoke ended. }\end{array}$ \\
\hline $\begin{array}{lr}\text { Sexy } & \text { Dancer } \\
\text { without } & \text { sexual } \\
\text { intercourse }\end{array}$ & $\begin{array}{l}\text { Rp.600,000 / sitting } \\
\text { cash }\end{array}$ & $\begin{array}{l}\text { For the cash sitting service, the dancers usually } \\
\text { accompany the guests from the beginning to the } \\
\text { end of the operating hours of the night } \\
\text { entertainment. Invite guests to chat, pour drinks, } \\
\text { eat and dance with guests. }\end{array}$ \\
\hline Sexy Dancer ++ & $\begin{array}{l}\text { Rp.600,000 / sitting } \\
\text { cash \& Rp. } 700,000 \\
\text { for sexual services . }\end{array}$ & $\begin{array}{l}\text { For the cash sitting service, the dancers usually } \\
\text { accompany the guests from the beginning to the } \\
\text { end of the operating hours of the night } \\
\text { entertainment venue, even though the fare is } \\
\text { quite expensive, but actually the tariff is still } \\
\text { shared with the management and management. } \\
\text { For sexual services, it is usually negotiated in } \\
\text { the back of the room and only decides when to } \\
\text { meet. Because if in a state of intoxication the } \\
\text { guests are usually reluctant to continue sexual } \\
\text { relations. }\end{array}$ \\
\hline \multirow{2}{*}{$\begin{array}{l}\text { Call Girl } \\
\text { (rates do not apply } \\
\text { to all } \\
\text { Comforters) }\end{array}$} & $\begin{array}{l}2 \text { Million / } 24 \text { hours } \\
\text { in Central } \\
\text { Kalimantan }\end{array}$ & $\begin{array}{l}\text { Does not serve anal sex, serves private parties, } \\
\text { and sex parties. }\end{array}$ \\
\hline & $\begin{array}{l}3.5 \text { Million } / 24 \\
\text { hours, outside } \\
\text { Central Kalimantan }\end{array}$ & $\begin{array}{l}\text { Does not serve anal sex, serves private parties, } \\
\text { and sex parties. }\end{array}$ \\
\hline
\end{tabular}

Source: Processed Research Results, 2018.

\section{c. Social Construction in CSW Networks}

The term construction of social reality (social construction of reality) became famous since it was introduced by Peter L. Berger and Thomas Luckmann through his book entitled The Social Construction of Reality: A Treatise in the Sociological of Knowledge (1966). He described the social process through his actions and interactions, in which individuals create continuously a reality that is shared and subjectively experienced together. This theory is used to explain the phenomenon of commercial sex workers in nightclubs in the City of Palangka Raya.

This phenomenon is related to the actor or informant, the events that take place and how the informant acts as a construction in social reality. Frans M. Parera in Berger and Luckmann, 1990: xx) in Januarti, et al (2012) explained, the main task of the sociology of 
knowledge is to explain the dialectics between self and the socioculture world. This dialectic takes place in a process with three simultaneous "moments", from the analysis below:

\section{Externalization}

First is externalization (adjustment) with the sociocultural world as a human product. This adjustment is owned by every human being. In the case of the writer who is careful here externalization means the conditions of the song guides or karaoke guides who are being meticulous researchers. This adjustment is related to how they adapt to their customers, work environment, and how they find and attract consumers.

This adaptation takes place depending on the informant's own personality, there is a personality capital if observed when women who become CSWs quickly adapt when they live life into CSWs, and for example adaptation can be done quite briefly if the woman is a cheerful, friendly and fun person. Making it easier for himself to face new situations during the foray into the world of prostitution. The initial work that became from an SPG, sexy dancer, song guide can then be expanded to become a prostitute with the consequences of facing scorn and prejudice from the environment.

2. Objectivation

In the objectivation stage, namely is the existence of social interactions that occur in an intersubjective world that is institutionalized or experiences an institutionalization process. Institutional in this case relates to the institution that is the night entertainment spot which is the location of research researchers. As a place of entertainment, night clubs often become a place for the ongoing practice of prostitution. Social processes and actions occur through various places. Based on these results could be explained that the nightlife scene with a variety of characters and penyebutannya be one of the many nightclubs that most demand today. As part of the objectification in seeing this case of prostitution that prostitution itself according to its activity is divided into two namely registered and unregistered:

a) Registered prostitution

The perpetrators are overseen by the Vice Control section of the police, who are assisted and work closely with the Social Service and Health Services. In general they are localized in a certain area. Registered institutions have institutions or are organized. However, nightclubs or karaoke venues in Palangkaraya City do not all register, although they also provide prostitutes.

b) Unregistered prostitution

Included in this group are those who carry out prostitution in secret and wild, both individually and in groups. The actions are not organized, the place is not certain, they do not register themselves with the authorities. And this phenomenon is actually developing because of the many prostistus listed by the government. Usually the covert operations (transactions) of CSWs are carried out by the employees of the nightclub itself. This happens because some customers who book a room often ask whether this karaoke place provides prostitutes.

3. Internalization

In the internalization stage, it is understood as the process by which an individual identifies himself with social institutions or social organizations where the individual is a member. This identification is done initially by song guides, sexy dancers through various interactions and social actions towards customers who use their services. Identification provides a great influence on social life between people. Through identification humans can recognize themselves, through who he is, what role is taken in social life, how he relates to the environment and so on.

In the phenomenon of night entertainment, the identification process itself does not take place immediately, usually through various opportunities this will be seen when the way they 
identify themselves as ladies, song guides or CSWs. This identification can be seen through behavior, how to dress, talk and behave.

The process of identification itself is closely related to the process of adaptation. To begin self-identification someone will usually adapt to what they are facing. For example, to identify you as a teacher, then the individual must be someone who works as a teacher or teaching technician. This process was passed by the research informants. They begin to adapt to the new label they take, and then identify themselves as part of the activity (workers at nightclubs).

The identification process carried out by the entertainment workers tonight tends to be closed. See their work that has great potential and is filled with negative things according to the prevailing ethics that makes them often hide their real identities in public spaces. Different when they are at work locations, they are not reluctant to emphasize that their status is a ladies companion, independent song guides, call girls, or even prostitutes for all four of these things.

Although some of them are still shy to open in the work space, they usually tend to remain silent and wait for a response from guests or the agency. When in a public area for example on campus they will become a student, but the atmosphere is inversely proportional when they enter the room at the nightclub, where they are very expressive and easy to interact with the guests in the room, for example in terms of clothing, their ways interact and the circle of friends they make. When doing the work the ladies usually use a mini sexy dress that is tight enough to show curves. Use makeup on the face, perfume and attractive hair makeup. Although this identity is formed only in the workspace, CSWs usually behave differently when they are in the neighborhood where they live.

After going through these three stages, then we can see how the CSWs act and interact. Their actions are built through various aspects. They can be different people with different interactions. By recognizing the area, location and background of the other person, they also identify others so that they are able to act according to the rules they set.

So then at this stage of internalization it becomes a choice for each individual. Thus, the attitudes, actions and interactions they build cannot be separated from their responsibilities and burdens as comfort women.

\section{Conclusion}

Looking at the social construction side of the network of CSWs in the city of Palangka Raya, it can be concluded that nightlife is a possible place for CSWs to work with the profession. Starting as an SPG, then becoming a sexy dancer or song guide as stages that enable women to become prostitutes, the processes can overlap with each other depending on the side of friendship (network) or even offers from agencies in the night entertainment venues. These prostitutes can independently offer themselves or through an agency that has been determined either by the pimp or the nightclub management according to the customer's request, here it is seen that there are economic factors there is demand then there is supply. With the presence of commercial sex workers, it can be said that there is a relationship that the continuity of the business of night entertainment becomes important. 


\section{References}

Agusyanto, Ruddy. 2007. Jaringan Sosial dalam Organisasi. Jakarta: Rajagrafindo Persada.

Berger, Peter, L., and Luckmann, T. 1966. The Social Construction of Reality A Treatise in the Sociology of Knowledge. Published by the Penguin Group - Penguin Books

Damsar. 2002. Sosiologi Ekonomi, Jakarta, PT. RajaGrafindo Persada.

Destrianti, Febri dan Yessi, H. Studi Kualitatif Pekerja Seks Komersial di Daerah Jondul Kota Pekan Baru Tahun 2016. Jurnal Endurance 3(2) Juni 2018 (302-312).

Lendechy, H. M. V., and Villagómez, I. T. Rural Women Who Undertake and Empower Themselves: Comparative Analysis in Communities in Mexico. Budapest International Research and Critics Institute-Journal (BIRCI-Journal) (2): 20-30.

Moleong, Lexy, J. 2014. Metodologi Penelitian Kualitatif. Bandung: PT Remaja Rosdakarya. Nurdiyana, T. 2018. Construction of Banjar Women Beauty in Kalimantan Selatan Indonesia. Budapest International Research and Critics Institute-Journal (BIRCI-Journal) (1): 404412.

Parera, Frans, M. 1990, "Menyingkap Misteri Manusia Sebagai Homo Faber" Pengantar Peter L. Berger dan Thomas Luckmann, Tafsir Sosial atas Kenyataan-Sejarah tentang Sosiologi Pengetahuan, Jakarta: LP3ES.

Syam, Nur. (2010). Agama Pelacur: Dramaturgi Transendental. Yogyakarta: LkiS.

Sugiyono (2008). Metode Penelitian Pendidikan Pendekatan Kuantitatif, Kualitatif, dan R \& D. Bandung Alfabeta.

Suparlan, Parsudi. 1983 Manusia, Kebudayaan dan Lingkungannya : Perspektif Antropologi Budaya, dalam Manusia dalam Keserasian Lingkungan, Mohammad Soerjani dan Bahrin Samad (ed.). Jakarta : Lembaga Penerbit Fakultas Ekonomi Universitas Indonesia.

Suparno, Paul. 1997. Filsafat Konstruktivisme Dalam Pendidikan, Yogyakarta: Kanisius.

Januarti, Raisa. Dkk (2012). Konstruksi Realitas Pemberitaan Brankas Nazaruddin Dalam Laporan Utama Majalah Tempo

http://journal.unpad.ac.id/index.php/ejournal/article/download/1133/pdf. Diakses 28 Juni 2020, Pukul 19.12 WIB

Mudzakir. 2014. Hukum Islam di Indonesia dalam Perspektif Konstruksi Sosial Peter L. Berger. Jurnal Al-'Adalah Vol. XII, No. 1 Juni 2014.

https://media.neliti.com/media/publications/57682-ID-hukum-islam-di-indonesiadalam-perspekti.pdf diakses 28 Juni 2020, pukul 09.45 WIB

Ngangi, Charles R. (2011) Konstruksi Sosial dalam Realitas Sosial-Ase-Volume 7 Nomor 2, Mei 2011: 1 - 4. https://media.neliti.com/media/publications/76686-ID-konstruksisosial-dalam-realitas-sosial.pdf. Diakses 28 Juni 2020, pukul 10.34 WIB 